\title{
PENGEMBANGAN MATERI PENDIDIKAN AGAMA ISLAM BERBASIS RUMAH
}

\section{THE DEVELOPMENT OF HOME-BASED ISLAMIC RELIGIOUS EDUCATION MATERIALS}

\author{
Suhardin', Hayadin ${ }^{2}$, Sugiarti $^{3}$, Ani Marlina ${ }^{4}$ \\ ${ }^{I}$ Universitas Ibnu Chaldun (UIC) Jakarta \\ ${ }^{2}$ Puslitbangpenda Balitbang Kemenag RI \\ ${ }^{3}$ Pengawas Sekolah Dinas Pendidikan Jawa Barat \\ ${ }^{4}$ STKIP Kusumanegara Jakarta \\ email: suhardi@yahoo.com
}

Naskah Diterima: 15 November 2021; Direvisi: 16 November 2021; Disetujui: 28 November 2021

\begin{abstract}
This article aims to discuss the development of Islamic religious education materials available for parents at home. The significance of home-based materials was motivated by the paralysis of the school's function in serving the learning process, including children's religious education, when the COVID-19 outbreak hit the world. This article comes from research and development involving education stakeholders, especially teachers, supervisors, and parents. The activities in focus group discussions were carried out in three places, namely in Bandung, Serpong, and Surabaya. Awareness of the importance of minimal material for parents at home to teach and educate their children about Islam is one of the reasons why this research was conducted. The main question is, what is the minimum content of Islamic religious education that parents should teach at home. After going through a series of discussions at three workshop locations, it was concluded that the material for Islamic religious education at home should be more straightforward and complementary to the subject matter of Islamic religion at school. The materials include the creed of monotheism, aqidah (theology), which discusses Allah SWT; worship (ritual) includes prayer, fasting; muamalat, which includes the introduction of buying and selling and transactions in Islam; and morality.
\end{abstract}

Keywords: Home-based; Islamic education; Learning center; Material development

\begin{abstract}
Abstrak
Artikel ini bertujuan untuk mendiskusikan pengembangan materi minimal pendidikan agama Islam yang dapat digunakan oleh orang tua dan pendidik di rumah. Ini dilatarbelakangi oleh lumpuhnya fungsi sekolah dalam melayani proses pembelajaran termasuk pembelajaran pendidikan agama anak saat wabah covid-19 melanda dunia. Artikel ini berasal dari riset dan pengembangan yang melibatkan stake-holders pendidikan khususnya guru pendidikan agama Islam, pengawas pendidikan agama Islam, dan orang tua. Kegiatan pengembangan berbentuk fokus grup diskusi dilakukan pada tiga tempat yakni di kota Bandung, kota Serpong dan kota Surabaya. Kesadaran tentang pentingnya materi minimal bagi para orang tua di rumah untuk mengajar dan mendidik anaknya tentang agama Islam menjadi salah satu alasan mengapa riset ini dilakukan. Pertanyaan utamanya adalah, apa konten minimal pendidikan agama Islam yang harus diajarkan oleh orang tua di rumah. Setelah melewati serangkaian diskusi pada tiga lokasi workhop, disimpulkan bahwa materi pendidikan agama Islam di rumah mesti lebih sederhana, dan bersifat komplementer dengan materi pelajaran agama Islam di sekolah. Materi tersebut meliputi: akidah tauhid, aqidah (teologi) yang membahas tentang Allah SWT; peribadatan (ritual) mencakup Shalat, puasa, doa-doa; muamalat yang meliputi pengenalan jual beli dan transaksi dalam Islam; dan akhlaq.
\end{abstract}

Kata kunci: Pendidikan Agama Islam; Pengembangan bahan ajar; Rumah sebagai pusat pendidikan agama 


\section{PENDAHULUAN}

Pandemi COVID-19 mengubah banyak hal dalam cara hidup manusia di dunia, tidak ketinggalan urusan pendidikan. Sistem Pendidikan berbasis sekolah, seolah-olah lumpuh menghadapi situasi pandemi covid-19. Sekolah mulai dari jenjang Pendidikan anak usia dini hingga jenjang pendidikan tinggi sepi, hanya ada petugas keamanan dan kebersihan. Semua melakukan aktivitas belajar dan mengajar di rumah, dengan istilah BDR (Belajar Dari Rumah). Seluruh komponen pendidikan; peserta didik, pendidik dan tenaga kependidikan, dan orang tua, dipaksa beradaptasi dengan keadaan tersebut. Sekalipun sekarang sudah ada PTM (Pembelajaran Tatap Muka), tetapi belum optimal, hanya dilakukan 50\% (lima puluh persen)(Kemendikbud, 2021). Civitas akademik harus memikirkan cara lain dalam penyelenggaraan pendidikan. Dunia belum pernah mengalami situasi ini, sehingga belum ada pola atau prosedur yang secara mudah bisa direplikasi. Seluruh pemerintahan negara di dunia yang menggantungkan proses pendidikan pada sekolah, sekarang bingung, tertekan dan belum menemukan solusi yang tepat. Paradigma pendidikan berpusat di sekolah perlu berevolusi, beradaptasi, berimprovisasi, berinovasi, menggali, mengkaji, dan menterapi model alternatif yang strategis dan solutif.

Para ilmuwan telah banyak mengkaji, membahas, dan menganalisis permasalahan rumah sebagai pusat pendidikan selama pandemi covid-19. Puslitbang Pendidikan Agama dan Keagamaan menemukan bahwa orang tua menjadi actor pendidik, pengajar, fasilitator layanan Pendidikan Agama pada saat pandemi berlangsung (Agama et al., 2020). Suhardin juga menemukan fakta belum optimal pembelajaran daring, karena faktor sumber daya manusia, pengaturan penyelenggaraan kurikulum, maupun sarana belajar (Suhardin et al., 2021). Sementara Agusriani dan Fauziddin (2021) mengemukakan ketidaksiapan guru dan siswa, karena siswa harus mampu memahami materi tanpa berhadapan dengan guru. Pemilihan strategi pembelajaran daring, perlu mempertimbangkan kemampuan siswa, kemampuan orang tua siswa dalam membantu dan tempat tinggal siswa (Yuangga \& Sunarsi, 2020; Izzah, 2020).

Bagi orang tua dengan status ekonomi menengah ke atas permasalahan dan kendala belajar di rumah, tidak begitu mereka rasakan. Mereka memiliki sumber daya untuk mengantisipasinya, mendatangkan guru, tutor dan pembimbing ke rumah. Tetapi bagi kelas menengah ke bawah, BDR permasalahan yang sangat kompleks; tempat belajar, pembimbing anak belajar, bahan ajar, jaringan internet, smartphone, notebook dan laptop. Hal ini pernah ditemukan dalam penelitian sebelumnya juga bahwa kendala orang tua dalam mendampingi anak BDR pada masa pandemi Covid- 19 adalah kurang materi ajar dari orang tua, kesulitan menumbuhkan minat belajar anak, tidak memiliki cukup waktu untuk mendampingi anak karena harus bekerja, orang tua tidak sabar dalam mendampingi anak saat BDR, kesulitan orang tua dalam mengoperasikan gadget, dan kendala terkait jangkauan layanan internet (Wardani \& Ayriza, 2020). Permasalahan ini pernah menjadi perbincangan dalam diskusi di kantor Puslitbang Pendidikan Agama dan Keagamaan untuk membantu orang tua siswa dalam bentuk bahan ajar pendidikan agama, namun yang menjadi permasalahan bagaimana bahan ajar pendidikan agama, apakah bahan ajar dalam bentuk pedoman atau dalam bentuk buku suplemen atau dalam bentuk buku saku.

Penelitian terdahulu banyak mengkaji, dan membahas permasalahan yang tengah dihadapi masyarakat selama pandemi Covid-19, tetapi belum ada yang memberikan solusi yang responsif, conkrite, dan produktif serta inovative untuk bekal bagi masyarakat yang tengah mengalami kesulitan. Novelty penelitian ini berada pada ranah tersebut. Penelitian ini berusaha memberikan terobosan konkrite sebagai responsif terhadap permasalahan yang tengah dan sedang dihadapi masyarakat. Menyajikan hal-hal yang produktif, inovatif serta dapat dimassifikasi untuk sebuah solusi dalam materi, content dan bahan ajar pendidikan Agama Islam dalam program rumah sebagai Pusat Belajar Pendidikan Agama. Artikel ini memberikan gambaran tentang proses pengembangan materi Pendidikan Agama Islam dengan melakukan penyesuaian 
pada sepuluh langkah yang digariskan oleh Borg and Gall.

\section{KAJIAN TEORI}

Pendidikan agama merupakan hal yang esensial bagi anak, karena akan menentukan keberhasilan pembelajaran, dan keberhasilan kehidupan di dunia dan akhirat kelak. Pendidikan agama yang sukses akan berpengaruh terhadap kesuksesan pendidikan yang lain. Kegagalan pendidikan agama akan berakibat juga terhadap pendidikan yang lainnya. Justru itu peran serta berbagai kelompok sosial di tengah kehidupan masyarakat sangat dibutuhkan. Dalam Peraturan Menteri Agama di nyatakan bahwa Pendidikan Agama adalah pendidikan yang memberikan pengetahuan dan membentuk sikap, kepribadian dan keterampilan peserta didik dalam mengamalkan ajaran agamanya, yang dilaksanakan sekurang-kurangnya dalam mata pelajaran pada semua jalur, jenjang dan jenis pendidikan (Kemenag RI, 2014). Hal terebut menjadi dasar dalam membentuk mata pelajaran agama pada semua jalur, jenis dan jenjang pendidikan. Jalur, pendidikan formal, informal dan non formal. jenis, sekolah kejuruan, keagamaan dan non kejuruan. Sedangkan jenjang semenjak pendidikan usia dini, dasar, lanjutan, menengah, dan tinggi.

Pendidikan Agama Islam merupakan pilar pembentukan karakter yang utama, dalamnya diajarkan aqidah, al-Qur'an-Hadits, sejarah, dan akhlaq (Nur, 2013). Pendidikan Agama Islam bukan hanya berorientasi pengembangan Ilmu Pengetahuan, tetapi juga bagian dari usaha pembentukan karakter peserta didik. Beberapa content, materi ajar pendidikan agama Islam lebih menekankan, membina, membentuk kepribadian peserta didik menjadi manusia yang berakhlaq mulia. Mengimplementasikan nilai-nilai tauhid; asma'ul-husna, memahami asma' wa syifat, menjiwai af'al Allah dalam kehidupan. Melatih untuk senantiasa berubudiah kepada Allah SWT berbuat baik terhadap sesama makhluk ciptaan-Nya. Hal-hal yang terkait dengan semuanya, dapat dipelajari dengan membaca, memahami, mengkonsktruksi ayat-ayat Allah SWT dalam al-Qur'an dan Hadits Nabi Muhammad SAW.
Pembelajaran terjadi akibat interaksi antara pengajar dengan siswa yang sudah diprogramkan sedemikian rupa, direncanakan dengan matang, dilakukan dengan serius, menggunakan berbagai teknik dan strategi untuk menyampaikan materi yang sudah terprogram agar menghasilkan sesuatu yang sudah digariskan sebelumnya. Setidaknya dalam pembelajaran, terdapat, pertama guru, yang sudah memiliki perencanaan materi, strategi, dan capaian dari hasil pembelajaran yang dilangsungkan. (Afiuddin, 2005) Kedua, pembelajar, yaitu siswa yang telah memiliki kesiapan diri untuk menerima sejumlah materi, dan mengikuti sejumlah strategi yang telah di instruksikan pengajar kepadanya, serta mendapatkan penambahan kompetensi diri setelah mengikuti pembelajaran tersebut. (Pribadi, 2007) Ketiga, materi pembelajaran, bahan yang disampaikan pengajar kepada pembelajar untuk memberikan penambahan kompetensi diri pembelajar. (Hamlet et al., n.d.) Keempat, strategi, cara tertentu yang ditempuh oleh pengajar dalam rangka efektifitas penguasaan pembelajar terhadap materi ajar yang disampaikan oleh pengajar. (Handayani, 2021) Kelima, media pembelajaran, sejumlah peralatan, baik yang bersifat elektronik, non elektronik yang digunakan oleh pengajar untuk mempercepat tingkat penguasaan pembelajar terhadap materi pembelajaran yang disampaikan pengajar. (Handayani, 2021) Keenam, suasana pembelajaran (meliau), kondisi lingkungan pembelajaran yang mempercepat tingkat penguasaan pembelajar terhadap materi pembelajaran yang disampaikan oleh pengajar. (Hasan Baharun, 2015)

Pada umumnya, belajar itu berbasis sekolah, dan rumah berfungsi melengkapi kegiatan pembelajaran di sekolah. Bahkan ada sekolah yang berusaha untuk tidak mengganggu aktivitas anak di rumah, dengan melaksanakan program fulldayschool. Di saat pandemi covid19, kondisinya berubah karena rumah dijadikan pusat belajar bagi anak. Proses ini telah berlangsung semenjak tanggal 16 Maret 2020 dan diperpanjang dengan mempertimbangkan situasi di masing-masing daerah. Dari sisi sumber daya manusia, pendidik maupun peserta didik ada yang memang sudah siap. Tetapi banyak pula yang terpaksa harus siap 
menghadapi pembelajaran yang biasanya dilaksanakan secara tatap muka berubah menjadi sistem belajar jarak jauh secara daring (Arifa, 2020). Kapan kembali normal, menjadi pertanyaan yang tidak bisa dijawab. Kesiapan dalam pengertian bukan hanya pihak sekolah, tetapi kesiapan yang mendasar dalam hal ini adalah orang tua siswa, ibu dan bapaknya. Ibu dan bapak yang sudah siap dengan pembelajaran di rumah, tentu merancang sedemikian rupa terkait dengan, pertama, paket internet yang dibutuhkan anak. Kedua, ruangan khusus pembelajaran yang representatif untuk kenyamanan anak dalam melaksanakan pembelajaran. Ketiga, buku ajar dan media pembelajaran lain yang dibutuhkan dalam pembelajaran anak. Keempat, bila memungkinkan mendatangkan tutorial bantuan dalam pengerjaan tugas-tugas yang sudah diberikan guru terhadap anak (Suhardn, 2021).

Peran keluarga dalam pendidikan, memang tidak dapat dipungkiri. Ki Hajar Dewantara jauh sebelumnya telah mendengungkan tri pusat pendidikan yang meliputi (1). Alam keluarga yang membentuk lembaga pendidikan keluarga; (2) alam perguruan yang membentuk lembaga pendidikan sekolah; (3) alam lingkungan yang membentuk lembaga pendidikan masyarakat (Wardani \& Ayriza, 2020). Yudi latif menyatakan bahwa pihak yang bertanggung jawab atas penyelenggaraan pendidikan adalah lembaga keluarga yang mempunyai wewenang bersifat kodrati; lembaga negara yang mempunyai wewenang berdasarkan undangundang; dan lembaga keagamaan yang mempunyai wewenang berasal dari amanat Tuhan (Yudilatif, 2020).

Rumah sebagai pusat belajar tidaklah sesuatu yang baru dalam sistem pendidikan, semenjak dahulu rumah menjadi pusat belajar. Orang tua, ibu dan bapak merupakan figur utama dalam pembelajaran anak, saudara asistensi orang tua dalam membimbing adikadiknya, family, di luar keluarga inti, merupakan guru pengayaan bagi seorang anak dalam melakukan pembelajaran. Rumah merupakan sekolah pertama (madrasatul ula) bagi manusia. Para pemimpin dunia, pemimpin bangsa dan pemimpin agama, pada umumnya dilahirkan dalam keluarga yang mengedepankan pendidikan, cinta ilmu pengetahuan, menjadikan rumah sebagai sumber ilmu pengetahuan dan menjadikan rumah sebagai pusat belajar pada anak dan segenap keluarganya.

Covid-19 menyapa warga dunia, dan mengubah gaya hidup, serta melumpuhkan kemapanan tatanan yang ada. Kedigdayaan lembaga pendidikan kampus, sekolah dan madrasah, rapuh diterpa oleh pandemi. Pusat pendidikan berubah dari sekolah kembali ke rumah. Tetapi pihak rumah belum siap menerima tugas tersebut. Terkait dengan mentalitas, sarana prasarana, sumber daya, sumber belajar, didaktik, metodik pembelajaran, bahkan banyak di antara orang tua mengalami penurunan strategycoping dalam menghadapi permasalahan rumah sebagai pusat belajar (Suhardin, 2021). Pengembalian rumah sebagai pusat pendidikan perlu disambut, dipersiapkan dengan baik, dibantu oleh pemerintah dengan sedemikian rupa bukan hanya bantuan dalam bentuk paket data, juga perlengkapan sumber belajar harus menjadi perhatian serius.

Rumah sebagai pusat belajar perlu digalakkan bukan hanya karena covid-19. Kita harus berterima kasih kepada covid-19 sudah datang kepada kita memberikan pelajaran yang sangat berharga, mengingatkan kita untuk kembali kepada khittah, bahwa rumah adalah pusat belajar. Ke depan bagaimana segenap komponen anak bangsa untuk merancang, mengembangkan dan mengimplementasikan rumah pusat belajar. Rumah harus dirancang sebagai sebuah sekolah utama anak dan anggota keluarga. Orang tua memastikan bahwa kegiatan belajar anak berlangsung dengan baik, tertib dan efektif, dengan berusaha untuk menyediakan paket data yang cukup buat anak berselancar di dalam dunia maya, mengakses berbagai sumber belajar. Orang tua mengawasi dengan seksama, penuh keramahan pembelajaran yang dilakukan anak. Orang tua berkomunikasi dengan gurunya tentang instruksi yang sudah disampaikan guru kepada anak. Orang tua masuk dalam group whatsap anak, sehingga mengetahui perkembangan anak dalam program pembelajaran formal yang dilakukan guru. Orang tua menyediakan ruangan yang nyaman untuk anak dalam 
melakukan pembelajaran. Semua anggota keluarga harus saling mendukung pelaksanaan pembelajaran masing-masing. Kakak yang berada pada jenjang atas, membimbing adik yang belajar di jenjang bawah, orang tua tetap semangat memberikan motivasi, membimbing dan memberikan fasilitas kepada anaknya untuk penguatan kompetensi diri sang anak.

Atmosfier pembelajaran akan tercipta dalam keluarga apabila masing-masing pihak memiliki kesiapan, baik secara filosofis, antropoligis, sosiologis, psikologis, ekonomis dan infrastrukturalis. Permasalahan pembelajaran di rumah lebih komleksitas dibandingkan dengan sekolah, madrasah dan kampus, karena semua lokus kegiatan ada di sana. Satu diantara lokus yang harus dilakukan adalah pembelajaran. Orang tua dan anak harus memiliki kesiapan filosofis, bahwa rumah secara paradigmatik merupakan pusat kegiatan pembelajaran, pembelajaran di sekolah selama ini, mustahil akan sukses kalau tidak ditunjang oleh kegiatan pembelajaran di rumah. Kesiapan sosiologis, rumah merupakan lapisan sosial terdalam dan organisasi mikro sosial, konstribusinya sangat signifikan terhadap wajah kehidupan sosial kultural yang terjadi, keluarga yang baik, sukses, bahagia dan sejahtera berkontribusi signifikan terhadap masyarakat yang baik, sukses, bahagia dan sejahtera dan berimplikasi kepada negara yang kuat, maju, makmur aman sentosa. Kesiapan antropologis, terlihat dari bahwa nilai, norma, budaya yang dikembangkan di tengah kehidupan keluarga berkontribusi positif dan signifikan juga dengan budaya masyarakat sekitar serta berkontribusi langsung terhadap kemajuan budaya bangsa. Kesiapan psikologis, bahwa orang tua dan anak membutuhkan kenyamanan diri, ketenangan jiwa, dalam berinteraksi dan berkomunikasi serta melangsungkan transformasi competency. Hal ini tentu seorang orang tua yang menjadi nara sumber, guru, tutor anaknya membutuhkan the power of knowledge, bahan ajar yang cukup, materi yang siap, content pembelajaran yang kaya, sehingga ia memiliki kepercayaan diri (self efficacy) dalam mentransformasikan competency kepada anaknya. Kesiapan ekonomi, lebih kepada orang tua, yang telah memiliki chasflow rumah tangga, pendapatan dan pengeluaran keluarga yang balance, mengejar pendapatan yang lebih ketimpang pengeluaran, sehingga memiliki ketenangan dalam mentransformasikan berbagai hal kepada anaknya. Kesiapan insfrastrukturalis, rancang bangun rumah dipersiapkan sedemikian rupa, disamping kebutuhan istirahat, bermain, juga belajar dan beribadah. Rumah menjadi pusat belajar dan pusat peribadatan, sehingga konsep baityjannaty, (rumahku adalah sorgaku) terwujud secara nyata.

Materi pembelajaran telah disiapkan oleh masyarakat dunia di dalam dunia maya, yang senantiasa dapat diakses dengan jaringan internet. Perangkat google telah menyiapkan bigdata, aneka ragam informasi, content ilmu pengetahuan semua diberikan fasilitas untuk mengupload dan mendownload, google memfasilitas masyarakat dunia saling berbagi dalam pengetahuan dan teknologi. Fasilitas internet tersebut juga dimanfaatkan oleh negara dalam memberikan kemajuan layanan pendidikan dengan berbagai situs pembelajaran, diantaranya rumah belajar, ruang guru, quipperschool, brainly, zenius, teded, udemy, coldecamy, coursera dan lain-lain (Arifa, 2020). Guru juga banyak mengembangkan informasi dan teknologi dalam pembelajaran, googlemeet, zoommeeting, googleclassroom, whatshapgroup, googledrive, dan beberapa platform media pembelajaran lain (Irsyad Kamal, Egi Arvian, Kurnia, Adi, 2020). Guru banyak mengembangkan materi pembelajaran dalam bentuk modul dan bahan ajar virtual kepada siswa. Sehingga dengan demikian siswa sebagai peserta didik menentukan nasibnya dalam proses pembelajaran. Peserta didik yang tangguh, kuat, cekat, dan tertantang akan sangat berpeluang dalam menimba berbagai ilmu pengetahuan yang tersedia di tangannya sendiri. Tetapi sebaliknya peserta didik yang tidak memiliki keinginan yang tinggi untuk belajar, akan tertinggal, dan tertatih-tatih dalam mengikuti proses pembelajaran yang berlangsung secara bebas, merdeka dan berdaulat ini.

Pendidikan agama merupakan pembelajaran yang multi aspek, pertama bersifat kognitif, penyajian materi, bahan ajar, yang menuntut pembelajar menguasai secara konseptual (Pribadi, 2007). Memahami secara komprehensif, detail, rinci dan rigid, sampai 
kepada re-formulasi content dengan benar, tepat, dan akurat. Kedua, efektif, terkait dengan sikap, termasuk juga keyakinan (belief) (Sageman \& D, 2005) yang mengharuskan guru melihat gestur pembelajar, dalam menjalankan nilai-nilai keagamaan yang dia yakini dan dia jalankan dalam kehidupannya. Ketiga, psichomotorik (Gunadi, 2019), ritual-ritual keagamaan bukan hanya diketahui dan dipahami, tetapi harus dilakukan dengan cara yang benar. Hal ini memerlukan praktek yang dapat disaksikan oleh guru secara nyata pada pembelajar yang tengah diajar oleh guru. Pendidikan agama diperlukan luring dan daring juga. Tetapi dengan kerja sama antara guru, orang tua siswa dan masyarakat, semuanya dapat diselesaikan.

Materi pembelajaran yang diberikan guru secara daring, dapat dibantu oleh orang tua siswa dan tokoh agama setempat dalam memberikan bimbingan, praktek, dan membantu guru dalam memberikan nilai praktek. Tugas guru yang harus melakukan praktek ibadah kepada masing-masing siswa, dibantu oleh orang tua dan tokoh agama setempat. Oleh karena itu, maka materi pelajaran pendidikan agama secara umum dan pada batas standard minimal mesti dikenal, dipahami bahkan dikuasai pula oleh orang tua. Aspek tauhid, ibadah, ritul, muamalah, adab, akhlak, dibutuhkan oleh orang tua siswa dalam kemasan bahan ajar, yang bakal diajarkan, dipandu, dan dibimbingkan kepada anak dalam bentuk pengenalan, pemahaman, penghayatan dan pembiasaan dalam kehidupan sehari-hari di rumah. Rumah sebagai pusat belajar akan memiliki peran strategis mencetek, membina dan membangun generasi muda millennials yang memiliki pengenalan, pemahaman, penghayatan dan pengamalan terhadap ajaran Islam secara holistik dan berkemajuan dalam bingkai nusantara yang ramah.

\section{METODOLOGI}

Penelitian ini menggunakan pendekatan kualitatif dengan metode pengembangan (research and development). Desain penelitian menyesuaikan dengan tahapan yang telah digariskan oleh Borg and Gall sebagai berikut; (1) potensi dan masalah (stateoftheart); (2) mengumpulkan informasi merencanakan (planning); (3) desain produk (develop preliminery form of product); (4) validasi desain (data collected and analyzed); (5) perbaikan desain (main productrevision); (6) uji coba produk (main field testing); (7) revisi produk (operational product revision); (8) ujicoba pemakaian (operational field testing); (9) revisi produk lanjut (final productre vision); (10) pembuatan produk masal (dissemination and implementation) (Meredith D. Gall, Joyce P. Gall, 2007). Praktinya digambarkan dengan tabel sebagai berikut:

Tabel 1. Desain Research and Development

\begin{tabular}{ll}
\hline State ofthe Art & Temuan beberapa research tentang rumah pusat belajar \\
Planning & Diskusi expert \\
Developprelimineryformofproduct & Temuanexpertpoint bahasan PAI \\
Data collectedandanalyzed & Validasi dan temuan content PAI Workshop I \\
Main productrevision & Validasi dan temuan content PAI Workshop II \\
Main field testing & Validasi dan temuan content PAI Worshop III \\
Operationalproductrevition & Reasonable, effektive dan effisience untuk tingkat \\
& pendidikan rumah \\
Operationalfield testing & Ujicoba pemakaian, \\
Final productrevision & Revisi produk lanjut, content, materi dan bahan ajar \\
& pendidikan agama Islam di rumah \\
Disseminationandimplementation & Pembuatan produk masal \\
\hline
\end{tabular}

Prosedur penelitian yang dilakukan dalam penelitian ini, pertama, berawal dari hasil temuan riset isu-isu aktual Puslitbang Pendidikan Agama dan Keagamaan tahun 2020, yang menemukan fakta bahwa selama pandemi covid-19, peserta didik jenjang Pendidikan Dasar dan Menengah belajar Pendidikan Agama dari rumah, oleh guru agama di sekolah secara daring, dan juga dari orang tua langsung. Orang tua menjadi salah satu actor pendidik, 
pengajar, fasilitator layanan Pendidikan Agama pada saat pandemi berlangsung. Oleh karena itu, menjadi penting kiranya jika ada buku panduan atau sumber bagi orang tua untuk menjadi pegangan dalam mendidik anaknya baik selama masa pandemi covid-19, atau pada situasi setelahnya. Dari temuan ini terlihat masalah utama bagaimana mengembangkan buku sumber belajar pendidikan agama yang berisi di antaranya content, materi dan bahan ajar pendidikan agama yang dapat dijadikan orang tua untuk diajarkan kepada anaknya.

Kedua, untuk merumuskan format, bentuk dan desain buku ajar pendidikan agama di rumah tersebut, peneliti berusaha untuk mengumpulkan expert berdiskusi mencari formulasi terkait dengan materi ajar yang efektif, reasonable (wajar, masuk akal dan layak), authentic (asli dan shahih), karena ini menyangkut dengan keyakinan dan pembiasaan yang harus dilakukan anak di tengah keluarga dan dalam lingkungan kemasyarakatan. Ketiga, desain produk hasil diskusi para expert mengerucutkan bahwa desain materi, content dan bahan ajar pendidikan agama Islam di rumah meliputi lima hal yang utama; (1) teologi, aqidah tauhid yang memberikan fondasi keyakinan terhadap anak berkenaan dengan ilahiyat, nubuwat dan ruhaniyat; (2) ritual, ibadah mahdah dan ammah dalam keseharian yang harus dilakukan oleh anak; (3) civilization, aktualisasi Islam di tengah peradaban dunia, meliputi capaian peradaban yang sudah ditorehkan Islam dalam kemajuan dunia dan konstribusi Islam terhadap kemanusia dan alam semesta seperti zakat, infak dan sadaqah, philantropy dan voluntry ; (4) moral, akhlak, dimensi kebaikan yang dihasilkan dari keyakinan yang dalam terhadap ilahiyat, nubuwat dan ruhaniyat sehingga memancarkan taqwa, cinta dan ridha, ikhlas, khauf dan raja', tawakkal, syukur, muraqabah, dan tobat; (5) ethic, perilaku individual dan sosial dalam kehidupan di tengah-tengah masyarakat dalam bentuk; shiddiq, amanah, istiqomah, iffah, mujahadah, syajaah, tawadhu' malu, sabar, pemaaf, birrulwalidain, tanggungjawab, karib kerabat, silaturrahim, ukhuwah, musyawarah, amar ma'ruf nahi munkar, ketaatan terhadap pimpinan.
Keempat, validasi desain, desain yang dihasilkan oleh expert dicoba untuk dipresentasikan dalam forum workshop Rumah Sebagai Pusat Belajar Pendidikan Agama yang diselenggarakan oleh Puslitbang Pendidikan Agama dan Keagamaan Balai Pendidikan dan Latihan Kementerian Agama Republik Indonesia di hotel Marcuire Bandung pada tanggal 21-22 Oktober 2021 yang menghasilkan content, materi dan bahan ajar pendidikan agama dalam pokok bahasan yang digariskan oleh expert tersebut. Kelima, perbaikan desain, hasil validitas diujicoba lagi pada workshop Rumah Sebagai Pusat Belajar Pendidikan Agama yang diselenggarakan oleh Puslitbang Pendidikan Agama dan Keagamaan Balai Pendidikan dan Latihan Kementerian Agama Republik Indonesia di hotel Soll Marina Serpong pada tanggal 27-28 Oktober 2021 yang tetap mempertahan content, materi dan bahan ajar pendidikan agama dalam pokok bahasan yang digariskan oleh expert tersebut dengan lebih mempertajam dan memperluas cakupan ruang lingkupnya. Keenam, uji coba produk, lagi pada worshop Rumah Sebagai Pusat Belajar Pendidikan Agama yang diselenggarakan oleh Puslitbang Pendidikan Agama dan Keagamaan Balai Pendidikan dan Latihan Kementerian Agama Republik Indonesia di hotel Sahid Surabaya pada tanggal 3-4 November 2021 yang tetap mempertahan content, materi dan bahan ajar pendidikan agama dalam pokok bahasan yang digariskan oleh expert tersebut dengan lebih mempertajam dan mengembangkan bahan ajar yang reasonable dan authentic.

Ketujuh, revisi produk, bahan ajar yang telah dipandang reasonable, effektive dan effisience untuk tingkat pendidikan rumah, dicoba untuk dikritisi oleh user, dalam hal ini bimas Islam, dalam rangka melihat authentic penggunaan istilah, penempatan diksi dalam materi, content dan bahan ajar pendidikan agama di rumah. Kedelapan, ujicoba pemakaian, mencoba untuk digunakan pada beberapa sampling rumah tangga, dengan meminta tanggapannya terkait dengan efektifitas, efisiensi dan reasonable, productcontent, materi dan bahan ajar pendidikan agama Islam yang menjadi pegangan orang tua siswa dalam pendidikan agama Islam di rumah. Kesembilan, revisi 
produk lanjut, content, materi dan bahan ajar pendidikan agama Islam di rumah yang sudah diujicobakan dilakukan revisi sesuai dengan saran dan pendepat orang tua siswa di ruamh yang sudah menggunakannya. Hasil masukan orang tua siswa yang sudah menggunakan content, materi dan bahan ajar pendidikan agama Islam di rumah tersebut, dilakukan revisi seadanya untuk dapat digandakan secara massif. Kesepuluh, pembuatan produk masal, perbaikan yang dilakukan sesudah uji coba dilakukan penggandaan secara massif, sehingga menjadi buku pegangan orang tua siswa di rumah dalam menuntun anaknya pada pendidikan agama Islam di rumah.

Objek Penelitian dan subject penelitian ini para pemuka agama Islam, ustad, guru, penyuluh. Mereka bekerja dengan sungguhsungguh untuk melakukan validasi konsep yang dihasilkan oleh expert, berusaha untuk memperkaya, memperdalam, memperluas, dan mengembangkannya secara reasonable untuk pembelajaran pendidikan agama Islam untuk anak di rumah. Semua yang terlibat dalam penelitian ini diundang secara formal oleh Kepala Puslitbang Pendidikan Agama dan Keagamaan melalui Kepala Kantor Kementerian Agama Kota Bandung, Kota Tangerang Selatan dan Kota Surabaya. Semua mereka berpatisipasi penuh, bekerja dalam komisi, sub komisi dan menghasilkan produk content, materi dan bahan ajar pendidikan agama Islam di rumah.
Teknik Pengambilan data yang dilakukan oleh peneliti, terlibat langsung dalam diskusi yang dilakukan oleh pemuka agama, ustad, guru, penyuluh dan pejabat di lingkungan kantor kementerian agama kota Bandung, Tangerang Selatan dan Surabaya. Memfasilitasi mereka berdiskusi, presentasi, dan mengkompilasi semua content, materi dan bahan ajar pendidikan agama Islam yang dihasilkan untuk difinaliasi menjadi sebuah produk buku saku bagi orang tua siswa dalam memberikan tuntunan, pengajaran, dan pengayaan materi, content dan bahan ajar pendidika agama Islam di dalam pembelajaran yang diselenggarakan di rumah.

Pengolahan data dilakukan sedemikian rupa dengan berpedoman kepada sepuluh langkah yang digariskan oleh Borg and Gall dalam buku Educational Research an Introduction, melibatkan orang-orang yang berkompetence dalam hal permasalahan content, materi dan bahan ajar pendidikan agama Islam. Teknik Analisis Data yang dilakukan qualitative research dengan pendekatan analysis content. Materi yang sudah dihasilkan oleh para narasumber, dicoba validasi, seminasi, dan di finalisasi.

\section{HASIL DAN PEMBAHASAN}

Dari tiga workshop dan serangkaian fokus grup diskusi yang dilakukan, maka rumusan konsep untuk materi Pendidikan Agama Islam berbasis rumah mengerucut dengan model (Tabel 2):

Tabel 2. Materi Pendidikan Agama Islam Dalam Rumah Sebagai Pusat Belajar Pendidikan Agama

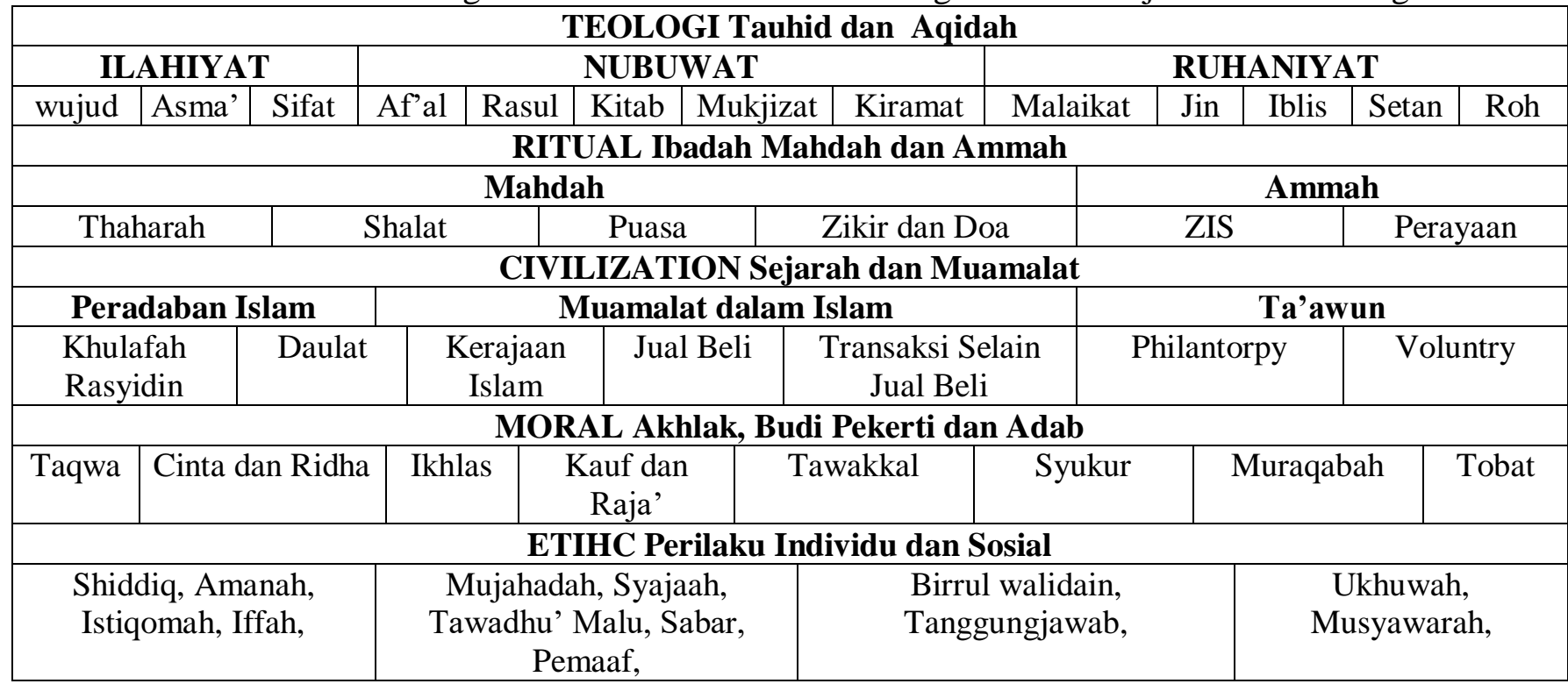




\section{Teologi: Aqidah, Tauhid}

Teologi berasal dari bahasa Yunani kuno theos ('dewa', 'Tuhan') dan logos ('wacana', perbincangan). Teologi dekat sekali dengan golongan yang ahli ketuhanan dan mereka yang membahas soal-soal ketuhanan (Khoirudin, 2015) Dalam bahasa keislaman dikenal dengan aqidahberkar dari kata 'aqada ya'qidu- 'aqdanaqidatan. 'Aqdan berarti simpul, ikatan, perjanjian dan kukuh. Ruang lingkup yang dibahas dalam kajian aqidah; Ilahiyat, pembahasan tentang segla sesuatu yang berhubungan dengan Ilah (Tuhan, Allah); wujud Allah, nama-nama, sifat dan af'al. Nubuwat, berhbungan dengan Nabi dan Rasul; kitab-kitab Allah, mukjizat, karamat. Ruhaniyat, berhubungan dengan alam metafisika: Malaikat, Jin, Iblis, Setan, dan Roh (Ilyas, 2014b) lebih lanjut Suhairi menjelaskan bahwa esensi iman kepada Allah SWT adalah Tauhid, mengesakan-Nya, baik dalam zat, asma'was-shiffat, maupun af'al (perbuatan)Nya. La Ilahaillallah merupakan kalimat thayyibah memiliki makna komprehensif: tidak ada yang maha mencipta kecuali Allah, tidak ada yang maha pemberi rezki kecuali Allah, tidak ada yang maha memelihara kecuali Allah, tidak ada yang maha pengelola kecuali Allah, tidak ada yang maha memiliki kecuali Allah, tidak ada yang maha memimpin kecuali Allah, tidak ada yang maha menentukan kecuali Allah, tidak ada yang maha menentukan Aturan kecuali Allah, tidak ada yang maha menjadi tujuan kecuali Allah, tidak ada yang maha disembah kecuali Allah (Ilyas, 2014b).

Pernyataan personal bertauhid kepada Allah, dideklarasikan secara nyata, terus terang, di depan umum sebagai pernyataan keimanan bagi seorang mukmin adalah dengan pernyataan dua khalimat syahadah, disebut juga dengan syahadatain. Asyhadu anlaa Ilaha illa llah wa asyhadu anna Muhamamad Rasulululah. Kata asyhadu secara etimologis dari kata syaha-da yang mempunyai tiga pengertian: musyahadah (menyaksikan), syahadah (kesaksian) dan half (sumpah). Ketiga pengertian ini dipakai di dalam al-Qur'an surat al-Thalaq (65:2), alMuthaffifin (83:21), al-Munafiqun (63:1) (Kemenag RI, 2015).

Semua misi Rasul menjalankan risalah Allah SWT memberikan penjelasan tentang visi dan misi kehidupan manusia sebagai hamba Allah SWT yang harus mempertanggungjawabkan seluruh perbuatannya dihadapan Allah kelak. Kepercayaan kepada hari kemudian adalah hal yang sangat esensial diajarkan kepada anak di rumah. Proses kebangkitan manusia (1) alam kubur, disebut juga dengan alam barzakh, membatasi antara alam dunia dan alam akhirat; (2) kiamat, kehancuran alam semesta, tiupan trompet Malaikat Israfil (QS. al-Zalzalah 99:1-3); (3) kebangkitan, dibangkitkannya nyawa makhluk hidup yang sudah mati. QS Yasin 36:52); (4) berkumpul di padang mahsyar, menunggu perhitungan (hisab) amal perbuatan manusia. (QS al-Isra' 17:79); (5) perhitungan dan penimbangan, dengan menyerahkan buku catatan manusia. (QS. al-Insyiqaq 84:7-12); (6) pembalasan, sesuai dengan hasil timbangan masing-masing (QS al-Qariah 101:6-9).

Selain dari beberapa hal yang disebutkan di atas, sebagai hal yang wajib diimani, juga yang perlu diyakini, diimani, dan diajarkan kepada anak di drumah, adalah terkait dengan taqdir Allah kepada manusia. Taqdir segala ketentuan, undang-undang, peraturan dan ketentuan yang ditetapkan oleh Allah SWT untuk segala yang ada yang mengikuti antara sebab dan akibat. Diantaratingkatakantaqdir (1) Al-Ilmu, pengetahuan Allah atas segala kejadian yang ada (QS al-Hajj 22:70); (2) AlKitabah, Allah telah menetapkan segala sesutunya di lauhulmahfuuz. (QS. Hajj 22:70); (3) Al-Masyiah, Allah mempunyai kehendak segala seuatu yang ada di langit dan yang di bumi. (QS. al-Insan 76:30); (4) Al-Khalq, Allah menciptakan segala sesuatu (QS. az-Zumar 39:62).

\section{Ritual, Ibadah Mahdah dalam kehidupan sehari-hari}

Ibadah yang perlu dibahas dalam pelajaran agama di rumah terkait dengan pertama, thaharah, artinya kesengajaan untuk membersihkan diri dari segala najis dan hadas. Najis segala sesuatu kotoran yang dapat menghalangi kesahan ibadah seseorang. Hadas segala sesuatu yang mengharuskan seseorang untuk mandi. Istinjak, whudu' dan mandi perlu bahas secara detail dan rinci sekaligus dengan bacaan-bacaannya, serta dalil-dalinya. Kedua, shalat, terkait dengan rukun, bacaan, kaifiayat 
dalam shalat. Tiga belas rukun shalat perlu dijelaskan secar rinci. Shalat wajib dengan jumlah rakaatnya; (1) subuh sebanyak dua rakaat; (2) Dzuhur sebanyak empat rakaat; (3) Ashar sebanyak empat rakaat; (4) Magrib sebanyak tiga rakaat dan (5) Isya sebanyak empat rakaat. Shalat-shalatsunnatdiantaranya; (SM, 2015) (1) shalatdhuha, dilaksanakan pada waktu matahari di atas ufuk; (2) shalatsunnat rawatib, shalatsunnat yang dilaksanakan berbarengan dengan shalat wajib, dianataranya, dua rakaat sebelum shalat subuh, dua rakat sebelum shalatdzuhur dan dua rakaat setelah shalatdzuhur, dua rakaat sebelum ashar, dua rakaat sebelum magrib dan dua rakaat setelah magrib, dua rakaat sebelum shalat isya dan dua rakaat setelah shalat isya; (3) shalattahajjud, dilaksanakan pada malam hari setelah bangun tidur menjelang shalat subuh; (4) shalat sunat tahiyyatul masjid, melaksanakan shalat dua rakaat setelah masuk masjid;

shalatsunnatwhudu', shalat dilaksanakan setelah menyelesaikan whudu'; (6) qiyamul Ramadhan, dilaksanakan pada malam bulan ramadhan, sering juga disebut dengan shalat tarawih; (7) shalat jenazah; (8) shalat gerhana.

Puasa juga perlu diberikan pembelajaran dengan menjelaskan konsep puasa secara rinci dan jelas, dan yang lebih penting dari itu juga dilatih dan dibiasakan kepada anak. Puasa dijelaskan bahwa ada puasa wajib dan ada puasa sunat. Puasa wajib dilakukan dalam bulan Ramadhan selama sebulan penuh, puasa yang telah diikrarkan sebagai nazar atas sesuatu, puasa pengganti dari puasa Ramadhan yang tidak dikerjakan karena mendapatkan halangan tertentu. Puasa sunat puasa yang dianjurkan, disunatkan kepada kaum muslimin untuk mengerjakannya, di antaranya; (1) puasa Senin kamis; (2) puasa arafah; (3) puasa enam hari pada bulan syawal; (4) puasa tasu'a, dilakukan tanggal sembilan Muharam; (5) puasa asyura, puasa pada tanggal sepuluh Muharram; (6) puasa Syakban, puasa yang dianjurkan pada bulan syakban; (7) puasa yaumul bidh, dilaksanakan tiga hari pada pertengahan bulan (Parenting, 2021).

Beberapa doa-doan penting yang perlu diajarkan kepada anak dalam pendidikan agama di rumah, diantaranya (1) doa menjelang makan dan doa sesudah makan; (2) doa mau tidur dan bangun tidur; (3) doa masuk toilet; (4) doa bepergian, berkendaraan; (5) doa dalam ketika sakit; (6) doa menjenguk orang sakit. (7) doa berbuka puasa; (8) doa sesudah Adzan. Disamping doa-doa juga diajarkan wirid, zikir dan lafaznya dengan jelas dan fasih, (1) zikir sesudah shalat wajib; (2) zikir dalam keseharian sebagai upaya untuk taqarrub ilallah. Ibadah secara umum dalam bentuk kebiasaan harian yang sangat dibutuhkan dalam pembelajaran rumah, bersedekah, menolong orang yang tengah kesusahan, membiasakan diri berbuat baik dengan lingkungan sekitar, memberi makan binatang, menyiram tanaman, menanam tanaman hijau di halaman, dipinggiranj rumah. Menghadiri beberapa perayaan hari besar Islam, terlibat dalam kegiatan maulid Nabi Muhammad SAW, Isra' dan Mi'raj Nabi Muhammad SAW dan beberapa kegiatan keagamaan, kegiatan sosial kemasyarakatan.

\section{Civilization: Peradaban dan Muamalat}

Kemajuan Islam dalam bidang peradaban, kebudayaan dan tatanan kehidupan muslim, perlu sekali diajarkan kepada anak dalam pendidikan di rumah. Diantara kemajuan Islam yang sangat penting, pertama, berkaitan dengan sejarah khulafaurrasyidin, (1) Abu Bakar Siddiq; (2) Umar bin Khattab; (3) Usman bin Affan dan (4) Ali bin Abi Talib. Hal ini merupakan pondasiperaban Islam yang perlu digali, dikaji dan disosialisasikan. Berikut kemajuan dan kejayaan Islam pada masa Daulah (1) Umayyah; (2) Abbasiyah dan (3) Daulah Umayyah di Andalusia. Hal ini terkait dengan beberapa kemajuan yang dicapai dalam bidang politik, kebudayaan, ilmu pengetahuan dan teknologi, merupakan masa keemasan Islam pada masa itu. Berikut dengan kemajuan Islam pada masa tiga kerajaan besar (1) Usmani; (2) Moghul dan (3) Persia. Masa kemunduran Islam dan masa kembali Islam untuk berusaha menggapai kemajuan. Hal ini dalam rangka memberikan gambaran kepada generasi muda bahwa Islam bukan hanya sekedar agama peribadatan, tetapi agama yang menginspirasi peradaban ummat manusia. Islam bukan untuk ummat Islam, tetapi Islam untuk manusia dan alam semesta (Ansari, 2009).

Muamalat merupakan sistem transaksi dalam Islam yang berkontribusi melahirkan 
peradaban. Diantara muamalat yang nyata adalah jual beli. Islam menghalalkan jual beli dan mengharamkan praktek riba. Jual beli dengan prinsip tolong menolong, dilakukan dengan transparansi, kejujuran, kejelasan. Nabi Muhammad adalah saudagar besar yang sukses mempraktekkan sistem jual beli berbasis kejujuran, transparansi dan kejelasan, sehingga menjadi konglomerasi papan atas di jazirah Arab. Perbankan Islam, menghindari praktek riba dengan melakukan transaksi berbasis jual beli, sehingga tidak ada penambahan nilai dalam bentuk bunga, tetapi keuntungan dalam transaksi jual beli. Sistem ini terbukti unggul dalam penyelenggaraan ekonomi global, tidak terkena imbas krisis moneter. Implementasi sistem transaksi dan muamalt keislaman berkontribusi terhadap peradaban manusia di dunia (Amstrong, 2014).

Ta'awun yang dilakukan dalam Islam dalam bentuk pengembangan Zakat, Infak dan Sadaqah yang telah diundangkan oleh pemerintah Republik Indonesia dengan Undang-Undang Pengelolaan Zakat yang dimplementasikan (1) lembaga pengelolaan zakat, plat merah dengan nama Badan Amil Zakat Nasional (Baznas), swasta yang dikelola oleh organisasi sosial keagaman Nahdlatul Ulama dan Muhammadiyah, dompet dhuafa, Aksi cepat Tanggap (ACT); (2) wakaf dalam bentuk wakaf uang dan wakaf tanah dalam rangka memajukan peradaban Islam, dengan melakukan kegiatan pendidikan (schoolling), layanan sosial (finding) dan layanan kesehatan (helling). Kegiatan ini wujud nyata dari philantorpy dan voluntryummat Islam untuk kepentingan kemanusiaan dan kemaslahatan alam semestas, perbaikan lingkungan serta partisipasi ummat Islam terhadap pembangunan yang berkelanjutan (sustainabledevelopment) (Suhardin, 2020).

\section{Moral: akhlak, budi pekerti dan adab.}

Moralitas nilai luhur yang keluar dari hati nurani yang dalam manusia, sebagai buah dari keimanan dan ketertiban ubudiah kepada Allah, diantaranya adalah (1) Taqwa, pemeliharaan diri dari perbuatan yang tidak disenangi oleh Allah SWT QS Ali Imran 3:133-135; (2) Cinta dan Ridha, memautkan hati kepada Allah SWT QS Ali Imran 3:31; (3) Ikhlas, bersih, jernih, murni, tidak bercampur, dalam bentuk nyatanya; (a) niat hanya karena Allah; (b) beramal dengan sebaik-baiknya; (c) memanfaatkan hasil usaha dengan sebaikbaiknya, setepat-tepatnya, tidak ada penyimpangan sedikitpun; (4) Kauf dan Raja', takut dan harap hanya kepada Allah SWT QS Yusuf 12:87; (5) Tawakkal, membebaskan hati dari segala ketergantungan selain Allah dan menyerahkan segala keputusan sesuatu kepadaNya QS Hud 11:123; (6) Syukur, memuji sipemberi nikmat atas kebaikan yang telah dilakukannya QS Lukman 31: 12; (7) Tobat, kembali kepada jalan yang benar, dari kekhilafan yang sudah dilakukan QS at-Tahrim 66:8; (8) Muraqabah, kesadaran yang tinggi bahwa diri diawasi oleh Allah SWT QS an-Nisa 4:1 (Ilyas, 2014).

\section{Ethics: Perilaku Individu dan Sosial}

Ethics merupakan nilai kepatutan, kepantasan, yang dilakukan oleh seseorang di tengah kehidupan sosial, kemasyarakatan dan di tengah lingkungan sekitar, wujud dari moralitas yang sudah ditempa oleh ubudiyah dan ketangguhan aqidah yang menjadi prinsip nilai dalam kehidupannya, diantaraethic bagi seorang muslim di tengah kehidupan: (1) siddiq, benar, jujur lawan dari pembohong dan pengkianat. (2) amanah, dipercaya sebagai akibat seseorang yang selalu memelihara kepercayaan orang terhadap dirinya; (3) istiqomah, sikap tegus dalam mempertahankan keyakinan yang dimiliki, hingga titik darah terakhir; (4) iffah, memelihara kehormatan diri dari segala yang merendahkan, merusak dan menjatuhkannya; (5) mujahadah, mencurahkan segala kemampuan untuk melepaskan diri dari segala yang menghambat pendekatan diri terhadap Allah SWT baik hambatan yang bersifat internal maupun eksternal; (6) syajaah, keberanian dengan landasan kebenaran dan dilakukan dengan penuh pertimbangan; (7) tawadhu, rendah hati, tidak sombong; (8) malu, tidak mengerjakan hal-hal yang merendahkan diri; (9) sabar, menahan diri dari segala sesuatu yang tidak disukai karena Allah; (10) pemaaf, memberikan maaf terhadap kesalahan orang lain dengan tidak ada rasa keinginan untuk membalas; (11) birrulwalidain, berbuat baik kepada kedua orang tua (ibu dan bapak); (12) tanggung jawab, kesiapan untuk menunaikan segala tugas yang diemban dengan sebaik- 
baiknya, kesiapan mengambil risiko terhadap kelalaian yang dilakukan; (13) ukhwah, menjaga silaturahmi antar muslim dan menjalin hubungan harmonis dengan non muslim; (14) musyawarah, dialog interaktif antar pihak dalam menyelesaikan permasalahan yang ada.

\section{PEMBAHASAN}

Konsep model materi pendidikan agama Islam berbasis rumah yang dinyatakan di atas, merupakan hal dinamis yang bisa mentriger dimulainya menyusun atau mempublikasikan materi pendidikan Islam untuk orang tua di rumah. Sejauh ini, materi pendidikan agama Islam yang banyak tersebar dan berkembang adalah buku pelajaran berbasis sekolah (Permendikbud_Nomor 20 Tahun2016 Tentang Standar Kompetensi Lulusan Pendidikan Dasar Dan Menengah, 2016), berbasis organisasi sosial keagamaan, atau berbasis bisnis percetakan (Sistem Perbukuan, 2017). Buku teks pelajaran agama Islam di sekolah sangat formal dengan ruang lingkup cakupan yang sangat luas (Nisyak, 2015; Mahmudah, 2016; Hayadin, 2019)

Jika dilihat kategori materi, yakni: akidah, ibadah ritual, muamalah, dan akhlak; ada sedikit perbedaan dengan ruang lingkup kategori materi pada buku teks pelajaran pendidikan agama Islam di sekolah yang meliputi: akidah, ibadah, sejarah, akhlak, alquran (Permendikbud_Nomor 20 Tahun2016 Tentang Standar Kompetensi Lulusan Pendidikan Dasar Dan Menengah, 2016). Hal ini dapat dipandang sebagai penyederhanaan atau penyesuaian content pelajaran agama berdasarkan tingkat kompetensi atau literasi orang tua di rumah dalam mengonsumsi informasi dan teks pelajaran pendidikan agama. Orang tua siswa harus dipandang sebagai subyek belajar yang memiliki banyak keterbatasan untuk belajar berdasarkan sistematika materi pelajaran pendidikan agama di lembaga pendidikan formal. Orang tua siswa rata-rata memiliki kesibukan mencari nafkah, dengan mata pencarian yang beragam dan tingkat pendidikan yang juga beragam.

Riset yang dilakukan oleh Puslitbang Pendidikan Agama dan Keagamaan bersama PIM UIN Jakarta (2019), menemukan fakta bahwa orang tua dan guru, mengharapkan tiga hal utama yang diperoleh dari pelajaran pendidikan agama yakni, menciptakan siswa yang terampil dan paham baca-tulis Al-Quran, rajin menunaikan ibadah shalat, dan berkarakter baik (menghormati orang tua). Dari sisi pengembangan kurikulum, hal tersebut mengandung arti, bahwa kurikulum pendidikan agama Islam di sekolah terlalu luas melebihi ekspektasi orang tua.

Kehadiran wabah covid-19, mendorong upaya penyederhanaan kurikulum dan konten pembelajaran pendidikan agama Islam menjadi realistis sebagaimana diatur dalam Panduan kurikulum darurat pada madrasah (2020), dan Panduan penyelenggaraan pembelajaran pada tahun ajaran 2020/2021 di masa pandemi covid19 (2020). Pada saat pandemi, setiap sekolah mengkreasi kurikulum darurat, termasuk untuk pelajaran pendidikan agama Islam (Prasetia \& Fahmi, 2020). Meskipun sekolah dan guru pendidikan agama Islam sudah menyederhanakan kurikulum tetapi situasi pembelajaran di rumah tetap membutuhkan dukungan orang tua, yang selama ini tidak dikondisikan atau disiapkan untuk mengambil alih peran atau fungsi pembelajaran di sekolah.

Harapan orang tua ini, sekarang dikembalikan kepada orang tua, anak bukan hanya sekedar tiga hal itu, tetapi juga menyangkut kompetensi Pendidikan Agama anaknya, meliputi antara lain: pertama, kognitif, pengenalan secara utuh, komprehensif, dalam dan tajam terkait dengan konsepsi ajaran agama Islam mencakup; aqidah, ibadah, muamalat, dan akhlaq. Kedua, ranah afeksi, terkait dengan penghayatannya terhadap ajaranajaran agama yang mencakup aqidah, ibadah, muamalat, dan akhlaq. Ketiga, psicomotoric, behaviouristic, pengamalan yang dilakukan dengan cara pembiasaan dalam kehidupan semua dimensi ajaran Islam yang meliputi aqidah, ibadah, muamalat, dan akhlaq.

Pemerintah selain memperhatikan terkait dengan kecerdasan anak untuk masa depan, juga perlu memperhatikan, membantu (advokasi), memberdayakan dan menguatkan kemampuan orang tua dalam mewujudkan rumah sebagai pusat belajar pendidikan agama Islam. Satu diantarakonstribusi pemerintah dalam membantu, memberdayakan dan menguatkan peran orang tua dengan 
memberikan bekal bahan ajar, materi, dan content Pendidikan Agama Islam dalam program Rumah sebagai Pusat Belajar Pendidikan Agama. Peran lain yang menanti di depan adalah melakukan pendidikan parenting.Parenting dapat meningkatkan kualitas pendidikan keluarga. (Nur, 2013) Kemajuan teknologi informasi di keluarga, literasi teknologi informasi, produk teknologi digital, seleksi media untuk anak, monitoring kegiatan belajar anak di rumah. (Nur, 2013) Dengan demikian dapat dipastikan bahwa orang tua memilki the power of knowledge, the power of personality, dan the power of capability. Rumah sebagai pusat belajar Pendidikan Agama terwujud secara massif di bumi nusantara.

Sekain itu juga yang tidak kalah pentingnya menyelesaikan masalah semenjak dari hulu, pendidikan pra nikah dengan program yang perlu dikaji, diteliti, dan dikembangkan lagi untuk menjawab permasalahan yang terjadi dalam rumah tangga. Permasalahan selama ini cukup menyesakkan dada, ditambah dengan tantangan yang menghadang untuk menjadikan rumah sebagai pusat pendidikan. Kemampuan ini perlu dilatih sedini mungkin, dengan pendidikan pra nikah oleh penyuluh, KUA, organisasi kemasyarakat keagamaan Islam, Nahdlayul Ulama, Muhammadiyah dan organisasi keislaman lainnya

\section{PENUTUP}

Bahan ajar, materi, content pembelajaran Pendidikan Agama Islam telah dilakukan seminasi dengan prosedural yang ketat, validasi yang akurat, implementasi yang terpantau, sehingga dapat dijadikan bahan ajar materi, content pendidikan Agama Islam dalam program Rumah sebagai Pusat Pendidikan Agama. Bahan ajar, materi, dan content Pendidikan Agama Islam meliputi aspek, pertama tauhid, aqidah (teologi) yang membahas tentang Allah SWT dalam ke-Ilahian, Nubuwat, dan Ruhiyat. Kedua, peribadatan (ritual) mencakup shalat, puasa, doa-doa, bacaan al-Qur'an, zakat dan sadaqah, dan konsep Ibadah Haji. Ketiga, muamalat, jual beli dan trasaksaksi dalam Islam, sejarah Islam. Keempat, akhlaq yang bersentuhan langsung dengan Allah dan Rasul, mencakup di dalamnya taqwa, cinta, ikhlas, khauf, tawakkal, syukur, muraqabah dan tobat. Kelima, akhlaq yang bersentuhan dengan personality, perilaku sehari-hari mencakup: shiddiq, amanah, istiqamah, iffah, mujahadah, syaja'ah, tawadhu', malu, sabar, pemaaf, ukhwah dan musyawarah.

Rumah sebagai pusat belajar Pendidikan Agama Islam, dibutuhkan kesiapan anak, orang tua, dalam hal philosofis, sosiologis, antropologis, psikologis, ekonomis dan infstrukturalis. Pemerintah perlu melakukan advokasi, membantu, memberdayakan, menguatkan orang tua siswa dengan bahan ajar, materi dan content Pendidikan Agama Islam juga melakukan pharenting, agar keluarga kuat, bahagia dan sejahtera berkontribusi terhadap masyarakat yang kuat, bahagia dan sejehtera sehingga terwujud Negara Kesatuan Republik Indonesia maju, makmur berkeadilan.

\section{UCAPAN TERIMAKASIH}

Kami sangat berterima kasih kepada Ibu Kepala Puslitbang Pendidikan Agama dan Keagamaan Kementerian Agama RI, yang memberikan kepercayaan kepada kami dalam penelitian ini melalui kegiatan Workshop Rumah Sebagai Pusat Belajar Pendidikan Agama. Demikian pula kepada Kepala Kantor Kementerian Agama Kota Bandung, Tangerang Selatan dan Surabaya yang telah mendukung dan berpartisipasi aktif dalam penelitian ini; Pemuka Agama, Penyuluh Agama dan Guru Agama yang berpartisipasi. Dan juga kepada segenap tenaga layanan administratif di kantor Puslitbang Penda yang membantu kelancaran penelitian. Kami mendoakan semua amal Jariyah ini diberikan pahala oleh Allah SWT dijadikan amal saleh yang menjadi deposito kita kelak berhadapan dengan-Nya.

\section{DAFTAR PUSTAKA}

\section{Afiuddin. (2005). Perencanaan dan Berbagai Pendekatan dalam Proses Belajar Mengajar. Insan Mandiri.}

Agama, P., Keagamaan, D. A. N., Peneliti, T., Pendidikan, P., Dan, A., Pendidikan, P., Dan, A., \& Pengantar, K. (2020). Isu-Isu Aktual.

Agusriani, A., \& Fauziddin, M. (2021). Strategi Orangtua Mengatasi Kejenuhan Anak 
Belajar dari Rumah Selama Pandemi Covid-19. Jurnal Obsesi: Jurnal Pendidikan Anak Usia Dini, 5(2), 17291740.

https://doi.org/10.31004/obsesi.v5i2.961

Amstrong, K. (2014). Islam : a short story (Y. Liputro (ed.)). MIZAN.

Ansari, T. (2009). Dari Puncak Bagdad Sejarah Dunia Versi Islam (Q. SF (ed.); pertama). ZAMAN.

Arifa, F. N. (2020). Tantangan Pelaksanaan Kebijakan Belajar Dari Rumah Dalam Masa Darurat Covid-19. Info Singkat;Kajian Singkat Terhadap Isu Aktual Dan Strategis, XII(7/I), 6. http://berkas.dpr.go.id/puslit/files/info_si ngkat/Info Singkat-XII-7-I-P3DI-April2020-1953.pdf

Gunadi, D. I. P. (2019). Peran Orang Tua dalam Optimalisasi Tumbuh Kembang Anak untuk Membangun Karakter Jujur. 34-47.

https://doi.org/10.31227/osf.io/zdt3g

Hamlet, B., Buneng, D., \& Buneng, D. (n.d.). Implementasi Pendidikan Multikultural Siswa. 75-84.

Handayani, O. D. (2021). Persepsi Orangtua terhadap Pelaksanaan Belajar dari Rumah pada Pendidikan Anak Usia Dini. 5(2),

1754-1763. https://doi.org/10.31004/obsesi.v5i2.975

Hasan Baharun. (2015). Jurnal Pendidikan Pedagogik, Vol. 01 No. 01 Januari-Juni 2015. Penerapan Pembelajaran Active Learning Untuk Meningkatkan Hasil Belajar Siswa Di Madrasah, Jurnal Pendidikan Pedagogik, Vol. 01 No. 01 Januari-Juni 2015, 01(01), 39.

Hayadin. (2019a). Laporan Penelitian Evaluasi KIKD Kurikulum 2013 di kota Makassar.

Hayadin, H. (2019b). Developing Students' Attitude Toward Environment Through Religious Education In Schools. ICEASD\&ICCOSED 2019: International Conference on Environmental Awareness for Sustainable Development in Conjunction with International Conference on Challenge and
Opportunities Sustainable Environmental Development, ICEASD \& ICCOSED 2019, 1-2 April 2019, Kendari, Indonesia. 388.

Ilyas, Y. (2014a). Kuliah Akhlaq. LPPI UMY.

Ilyas, Y. (2014b). Kuliah Aqidah Islam (ke-6). LPPI UMY.

Irsyad Kamal, Egi Arvian, Kurnia, Adi, C. (2020). Pembelajaran di Era 4.0 Aplikasi Teknologi Informasi dalam Pembelajaran (Y. Mulyadi (ed.); pertama). Yrama Widya.

Panduan Kurikulum Darurat Pada Madrasah, Pub. L. No. 2791, 9 KEmenterian Agama 6 (2020).

Izzah, N. I. (2020). Pemilihan Strategi Sebagai Alternatif Solusi Permasalahan Pembelajaran Berbasis Daring. AlHikmah: Journal of Education, 1(1), 3546.

http://yphn.ac.id/ejournal/index.php/Alhi $\mathrm{kmah} / \mathrm{index}$

Panduan Penyelenggaraan Pembelajaran Pada Tahun Ajaran 2020/2021 dan Tahun Akademik 2020/2021 di Masa Pandemi Coronavirus Disease 2019 (COVID-19), (2020).

Kemenag RI. (2014). Peraturan Menteri Agama Nomor 13 tentang Pendidikan Keagamaan Islam. https://jatim.kemenag.go.id/file/file/PMA /ihdp1412150669.PDF

Permendikbud_Nomor 20 Tahun2016 tentang Standar Kompetensi Lulusan Pendidikan Dasar dan Menengah, Pub. L. No. 20 (2016).

Kemendikbud. (2021). Penyelenggaraan Pembelajaran Tatap Muka Tahun Akademik 2021/2022. 3.

Khoirudin, A. (2015). Teologi al-'Ashr Etos dan Ajaran K.H.A. Dahlan yang Terlupakan (A. Pratama (ed.); pertama). Suara Muhammadiyah.

Mahmudah, R. (2016). Analisis kualitas buku teks pelajaran pendidikan agama Islam dan budi pekerti kelas VII Sekolah Menengah Pertama (SMP) Kurikulum 
2013 di Kabupaten Malang. Universitas Islam Negeri Maulana Malik Ibrahim.

Meredith D. Gall, Joyce P. Gall, W. R. B. (2007). Educational Research. Longman.

Nisyak, S. (2015). Analisis kelayakan isi dan bahasa buku ajar pendidikan agama Islam dan budi pekerti Sekolah Menengah Pertama (SMP) kelas tujuh (VII) penerbit Kementerian Pendidikan dan Kebudayaan. Universitas Islam Negeri Maulana Malik Ibrahim.

Nur, A. (2013). Pendidikan Karakter Melalui Pendidikan Agama Islam. Al-Ulum, 13(Nomor 1), 25-38. http://www.journal.iaingorontalo.ac.id/in dex.php/au/article/download/179/159/

Parenting. (2021). 9+ Macam-macam Puasa Sunnah yang Dianjurkan Rasulullah SAW dan Waktu Pelaksanaannya, Catat! Ketahui juga keutamaan dari setiap puasa sunnah. Parenting. https://www.orami.co.id/magazine/puasa -sunnah/

Sistem Perbukuan, Pub. L. No. 3 (2017).

Prasetia, S. A., \& Fahmi, M. (2020). Reorientasi, Peran dan Tantangan Pendidikan Islam di tengah Pandemi. Tarbawi, 9(1), 21-38. https://doi.org/ 10.36781/tarbawi.v9i1.3128

Pribadi, B. A. (2007). Aplikasi Pendekatan Konstruktivistik Pada Bahan Ajar Sistem Pendidikan Jarak Jauh. Jurnal Teknologi Pendidikan, 9(2), 91-102.

RI, Kemenag. (2015). Al-Qur'an dan Terjemahan. Kementerian Agama.

Undang-Undang Sisdiknas Nomor 20 Tahun 2003, Pub. L. No. 20 Tahun 2003, 6 (2003).

https://doi.org/10.16309/j.cnki.issn.10071776.2003.03.004

Sageman, M., \& D, P. (2005). Understanding Jihadi Networks Strategic Insights, Volume IV , Issue 4 ( April 2005 ) The Evolution of the Global Salafi Jihad Ideology The History of the Global Salafi Jihad. Europe, IV(4).
SM, M. (2015). Bimbingan Shalat Nabi (pertama). PDM Sidoarjo.

Suhardin. (2021). Coping Strategy Masyarakat di Tengah Pandemi Covid-19 Effect Status Sosial dan Gender: Studi Expost Facto di Jakarta. Jurnal Pendidikan Islam, 2(2), 256-283.

Suhardin, S. (2020). Pendidikan Responsibility Philantropy Behaviour dan Intention To Pray Pada Siswa di Tengah Pandemi Covid-19. Intiqad: Jurnal Agama Dan Pendidikan Islam, 12(2), 290-310. https://doi.org/10.30596/intiqad.v12i2.51 95

Suhardin, S., Hayadin, H., \& Nurhayati, N. (2021). Instructional Meaningfully Implementation in Distance Learning The Era of Pandemy Covid-19. https://doi.org/10.4108/eai.11-112020.2308282

Suhardn. (2021). Pelayanan Pendidikan Di Rumah Berbasis Ramah Anak Di Era Pandemi Covid-19 Koping Strategi Dan Konsep Diri Orang Tua Siswa. Al-Ulum Jurnal Pendidikan Islam, 2 No. 1 $T a$ (Pendidikan), 37. https://doi.org/http://dx.doi.org/10.30596 \%2Fal-ulum.v2i1.104

Wardani, A., \& Ayriza, Y. (2020). Analisis Kendala Orang Tua dalam Mendampingi Anak Belajar di Rumah Pada Masa Pandemi Covid-19. Jurnal Obsesi : Jurnal Pendidikan Anak Usia Dini, 5(1), 772.

https://doi.org/10.31004/obsesi.v5i1.705

Yuangga, K. D., \& Sunarsi, D. (2020). PENGEMBANGAN MEDIA DAN STRATEGI PEMBELAJARAN UNTUK MENGATASI PERMASALAHAN PEMBELAJARAN JARAK JAUH DI PANDEMI COVID- 19. (Kharisma Dan Denok, 2020 ), 4(3), 51-58.

Yudilatif. (2020). Pendidikan yang Berkebudayaan History, Konsepsi, dan Aktualisasi Pendidikan Transformatif (A. Tarigan (ed.); kedua). Gramedia. 